\title{
Pengetahuan Dewan Tentang Anggaran Dalam Pengawasan Keuangan Daerah (APBD) di Kabupaten Sidoarjo
}

\author{
Santi Rahma Dewi*, Kukuh Sinduwiatmo, Sarwenda Biduri \\ Fakultas Bisnis Hukum dan IImu Sosial, Universitas Muhammadiyah Sidoarjo, Indonesia
}

This study aims to find out how the board's knowledge about the budget in implementing regional financial supervision (APBD). This research was conducted with qualitative methods by presenting elements of questions regarding the board's knowledge of budget and regional financial supervision. Methods of gathering information using interviews and documentation to members of the Sidoarjo Regency council. The results of this study indicate that board members understand the process of determining the budget carried out by the executive, so that they can supervise and control the implementation of the APBD in Sidoarjo Regency. And expect follow-up from the executive on recommendations that have been given by the legislature where so far there has been no follow-up done.

OPEN ACCESS ISSN 2548-3501 (online)

Edited by: Eny Maryanti

Reviewed by: Rahmawati

${ }^{*}$ Correspondence: Santi Rahma Dewi santirahma.d@gmail.com

Received: 12 April 2019 Accepted: 15 Juni 2019 Published: 31 Juli 2019

Citation:

SRD, KS and SB (2019)

Pengetahuan Dewan Tentang Anggaran Dalam Pengawasan Keuangan Daerah (APBD) di Kabupaten Sidoarjo. Journal of Accounting Science. 3:2. doi: 10.21070/jas.v3i2.2779
Keywords: Budget Knowledge, Regional Financial Supervision

Penelitian ini yang bertujuan untuk mengetahui bagaimana pengetahuan dewan tentang anggaran dalammelaksanakan pengawasan keuangan daerah (APBD).Penelitian ini dilakukan dengan metode kualitatif dengan menyajikan unsur-unsur pertanyaan mengenai pengetahuan dewan tentang anggaran dan pengawasan keuangan daerah. Metode pengumpulan informasi dengan menggunakan wawancara dan dokumentasi kepada anggota dewan Kabupaten Sidoarjo. Hasil dari penelitian ini menunjukkan bahwa anggota dewan memahami proses penentuan anggaran yang dilaksakan oleh eksekutif, sehingga dapat melakukan pengawasan dan pengendalian pelaksanaan APBD di Kabupaten Sidoarjo. Dan mengharapkan adanya tindak lanjut dari eksekutif atas rekomendasi yang telah diberikan legislatif dimana selama ini belum ada tindak lanjut yang dilakukan.

Keywords: Pengetahuan Anggaran, Pengawasan Keuangan Daerah 


\section{PENDAHULUAN}

Kesejahteraan rakyat merupakan tujuan utama dari kinerja pemerintah. Pemerintah berusaha mewujudkan pemerataan kesejahteraan terutama tentang fiskal dengan mempertahankan aspek keuangan yang dikelola dan bersumber dari pendapatan pajak serta beberapa sumber-sumber lainnya. Dalam pencapaian keseimbangan pemerintah harus mampu menyelaraskan proses politik untuk berbagai kepentingan masyarakat.

Sesuai dengan peraturan PP No. 58/2005 pemerintah telah membuat aturan sesuai dengan tuntutan masyarakat yaitu kepala daerah harus melakukan pertanggungjawaban (akunabilitas) dalam laporan keuangan daerah yaitu neraca daerah, arus kas dan realisasi anggaran. Seiring dengan munculnya gerakan reformasi yang membawa perubahan terhadap kehidupan politik di seluruh lapisan masyarakat. Salah satu yang terdampak dari perubahan ini adalah adanya desentralisasi keuangan dan otonomi daerah.

Implikasi positif yang muncul dari berlakunya UndangUndang tentang Otonomi Daerah yang berkaitan dengan kedudukan, fungsi dan hak-hak dari DPRD, diharapkan bahwa DPRD yang selanjutnya disebut dewan akan lebih aktif di dalam menangkap aspirasi yang berkembang di lingkungan masyarakat, yang kemudian akan diadopsi ke dalam berbagai bentuk kebijakan publik di daerah bersama-sama dengan Kepala Daerah (Bupati dan Walikota).

Secara umum, sesuai dengan Undang-Undang No 17 pasal 69 yang menjelaskan fungsi lembaga legislatif yaitu: "(1) fungsi legislasi (fungsi membuat peraturan perundang-undangan), (2) fungsi anggaran (fungsi untuk menyusun anggaran, dan (3) fungsi pengawasan (fungsi untuk mengawasi kinerja eksekutif)."

Dari berbagai informasi yang didapatkan bahwa dalam setiap tahun anggaran sering terjadi ketidak sesuaian antara pemerintah dengan dewan dalam perumusan anggaran dan sering terjadinya tarik ulur antara dewan dengan pemerintah untuk menentukan rencana anggaran, maka perlu ada pengkajian apakah anggota dewan telah memahami segala hal tentang anggaran agar bisa mencapai kata sepakat dalam penentuan RAPBD.

Oleh karena itu diharapkan dengan adanya penelitian ini dapat memberikan solusi atas adanya suatu perencanaan, penyusunan dan pengendalian yang transparan dan akuntabel. Oleh karenanya dalam penelitian ini dititikberatkan pada fungsi dewan sebagai fungsi pengawasan anggaran. Permasalahannya adalah apakah dewan dalam melaksanakan fungsinya dalam pengawasan lebih disebabkan pengetahuan dewan tentang anggaran ataukah lebih disebabkan karena adanya permasalahan lain.

\section{Keuangan Daerah}

Pengertian dari keuangan daerah menurut pasal 1 PP No 105 tahun 2000 adalah "semua hak dan kewajiban daerah yang ada dalam kerangka penyelengaraan pemerintahan yang dapat dinilai dengan nominal uang termasuk di dalamnya segala bentuk kekayaan yang berhubungan dengan hak dan kewajiban daerah tersebut dalam kerangka APBD."

Dari pengertian tentang keuangan negara tersebut di atas, maka pengertian keuangan daerah pada dasarnya sama dengan "pengertian keuangan negara di mana negara dianologikan dengan daerah. Hanya saja di dalam konteks ini keuangan daerah adalah semua hak-hak dan kewajiban suatu daerah yang dapat dinilai dengan uang.Demikian pula sesuatu baik uang maupun barang yang dapat dijadikan kekayaan daerah berhubungan dengan adanya pelaksanaan hak-hak kewajiban tersebut dan tentunya terdapat dalam batas-batas kewenangan daerah" (Ichsan (1997)

\section{Pengetahuan Dewan Tentang Anggaran}

"Pengetahuan dewan tentang anggaran merupakan kegiatan dalam mengetahuianggaran dan kemampuan dewan dalam kegiatan menyusun anggaran (RAPBD/APBD), pemeriksaan serta kegiatan identifikasi terhadap pemborosan anggaran atau kegagalan, dan kebocoran anggaran "(Yudoyono (2002)). Kemampuan dalam melaksanakan tugas mempunyai hubungan yang sangat erat bagi anggota dewan berkaitan dengan tingkat pengetahuan, tingkat keterampilan dan tingkat keahliannya. Oleh karena hal itu, peningkatan kemampuan seorang aparatur selalu diarahkan pada arah pendidikan serta pelatihan serta bertujuan dalam memerluas pengalaman aparatur melalui studi banding ke tempat lainyang mempunyai pengalaman lebih. Tujuan yang ingin dicapai melalui pendidikan dan pelatihan bagi sumber daya manusia terdapat padapengembangan dan peningkatan berbagai unsur sebagai berikut: a.Bertujuan dalam kegiatan pengembangan dan pelaksanakan tugas dan kewajiban sebagai seorang aparatur pemerintah, sehingga mampu memenuhi standar yang telah ditentukan untuk suatu tugas tertentu dan dapat mengambil keputusan secara mandiri dan professional dengan berbagai pertimbangan tertentu.b.Bertujuan dalam pelaksanan yang berkaitan dengan kegiatan yang berkaitan degan peningkatan motivasi, sikap disiplin, kejujuran, etos kerja, dan rasa tanggung jawab yang didasari oleh kesadaran masing-masing kepedulian individu.c.Bertujuan dalam merubahan sikap dan perilaku yang akan mengarah pada perkembangan sikap keterbukaan, sikap melayani serta perilaku mengayomi politik sebagai tugas dan tanggung jawab utamanya. Dalam usaha peningkatkan kinerja dalam pengawasan keuangan daerah, semua anggota dewan/DPRD harus mempunyai pengetahuan secara detail mengenai keseluruhan struktur dan proses anggaran.

Pengetahuan anggota dewan mengenai mekanisme tentang anggaran bersumber dari kemampuan anggota dewan yang diperoleh dari berbagai latar belakang pendidikannya ataupun dari pelatihan dan seminar yang berkaitan dengan keuangan daerah yang diikuti oleh anggota setiap dewan. Pembinaan /seminar mengenai keuangan daerah yang diikuti oleh setiap anggota dewan akan meningkatkan pemahaman 
anggota dewan bahwa proses alokasi anggaran bukan hanya sekedar suatu proses administrasi, akan tetapi juga merupakan proses politik. Pengetahuan dewan tentang anggaran mempunyai hubungan yang erat dengan fungsi penganggaran dan fungsi pengawasan yang dimiliki oleh setiap anggota dewan.Adapun fungsi penganggaran menyarankan bagi setiap anggota DPRD untuk selalu ikut berpartisipasi dalam kegiatan proses anggaran secara masal dengan pihak eksekutif.Adapun fungsi pengawasan DPRD menjelaskan secara detail mengenai kewenangan dalam melaksanakan pengawasan kinerja pihak eksekutif dalam pelaksanaan APBD.Dalam keadaan tertentu anggota DPRD disarankan secera paksa untuk mempunyai keterampilan dalam membaca anggaran serta mempunyai kemampuan yang berkaitan denganproses anggaran di daerah sehingga DPRD dapat melaksanakan tugasnya secara efektif dalam melakukan kegiatan pengawasan terhadap pelaksanaan anggaran.

\section{Pengawasan Keuangan daerah}

Pengawasan berdasarkan Keputusan Presiden No. 74 tahun 2001 (Tentang Tata Cara Pengawasan Penyelengaraan Pemerintah Daerah) Pasal (16) menyebutkan bahwa "pengawasan yang dilakukan pemerintah daerah adalah suatu proses kegiatan yang ditujukan untuk menjamin agar pemerintah daerah dapat berjalan sesuai dengan rencana dan ketentuan dari peraturan perundang- undangan yang berlaku".

Pengawasan yang dilakukan oleh anggota dewan dapat berupa pengawasan secara langsung maupun tidak langsung serta preventif dan represif. Pengawasan langsung akan dilakukan secara pribadi dengan cara ,melakukan tindakan mengamati, meneliti, memeriksa, mengecek sendiri di lokasi pekerjaan dan meminta secara langsung laporan dari pelaksana dengan cara inspeksi. Sedangkan tindakan pengawasan tidak langsung akandilakukan dengan cara mempelajari laporan yang telah diterima dari para pelaksana. Pengawasan secara preventif dilakukan melalui pre-audit yaitu sebelum pekerjaan akandimulai. Pengawasan secara represifakan dilakukan melalui post-audit dengan melakukan pemeriksaan terhadap pelaksanaan di tempat (inspeksi).

Yudoyono (2002) mengatakan " bahwa apabila DPRD dapat menggunakan hak- haknya secara tepat, melaksanakan segala tugas dan kewajibannya secara efektif serta menempatkan kedudukannya secara proposional apabila setiap anggota mempunyai dasar pengetahuan yang cukup dalam hal konsepsi tentang teknis penyelenggaraan pemerintahan, kebijakan publik, dan lain sebagainya. Pengetahuan yang dibutuhkan oleh anggota dewan dalam melakukan pengawasan keuangan daerah dimana salah satunya adalah pengetahuan tentang anggaran.Dengan mengetahui tentang dasar anggaran diharapkan anggota dewan akan dapat melakukan deteksi adanya pemborosan dan kebocoran anggaran."

"Adanya beberapa perubahan paradigma anggaran di era reformasi yang menuntut adanya partisipasi masyarakat (publik) dalam keseluruhan siklus anggaran.Untuk dapat mencip- takan akuntabilitas kepada publik diperlukan partsipasi kepala instansi dan warga masyarakat dalam penyusunan dan pengawasan anggaran" (Rubin (1996) . Achmadi et al. (2002) menyebutkan bahwa "suatu partisipasi masyarakat merupakansalah satu kunci sukses dari pelaksanaan otonomi daerah karena dalam partisipasi tersebut akan menyangkut aspek pengawasan dan aspirasi.Pengawasan yang dimaksudkan di sini termasuk pengawasan yang dilakukan terhadap pihak eksekutif melalui pihak legislatif.'

Peranan anggota dewan dalam melakukan pengawasan keuangan daerah akan sangat dipengaruhi oleh keterlibatan masyarakat dalam melakukan advokasi anggaran. Jadi, selain pengetahuan dewan tentang anggaran yang mempengaruhi pengawasan yang dilakukan oleh dewan, partisipasi oleh masyarakat diharapkan akandapat meningkatkan fungsi pengawasan.

Selain adanya partisipasi akuntabilitas dan masyarakat dalam siklus anggaran, transparansi anggaran juga diperlukan untuk meningkatkan pengawasan. Transparansi merupakan salah satu prinsip dari good governance. Transparansi dibangun di atas dasar arus informasi yang bebas dimana,seluruh proses pemerintahan ,lembaga-lembagadan informasi perlu diakses oleh pihak-pihak yang berkepentingan, dan informasi yang tersedia harus memadai agar dapat dimengerti dan dipantau.

\section{Pengetahuan Dewan tentang Anggaran dalam Pengawasan Keuangan Daerah}

"Setiap anggota dewan harus memiliki pengetahuan dasar yang cukup dalam halkonsepsi teknis penyelenggaraan pemerintahan dan kebijakan publik, karenaDPRD juga harus mampu menggunakan hak-haknya secara tepat, melaksanakan tugas dan kewajibannya secara efektif serta menempatkan kedudukannya secaraproporsional".(Coryanata (2007) .Dalam penelitian Pramita and Andriyani (2010), membuktikan bahwa "pengetahuan dewan tentang anggaran berpengaruh secara signifikan terhadap pengawasan keuangan daerah (APBD)"

Berkaitan dengan beberapa permasalahan yang telah muncul, maka penelitian ini diharapkan dapat memberikan informasi tentang bagaimana pengetahuan dewan akan anggaran dalam pelaksanaan pengawasan keuangan daerah(APBD).

\section{METODE PENELITIAN}

\section{Jenis Penelitian}

Dalam penelitian ini menggunakan metode penelitian kualitatif deskripstif., dimana peneliti akan melakukan perbandingan antara informasi dari informan sesuai dengan objek penelitian 


\section{Lokasi Penelitian}

Lokasi penelitian yang merupakan tempat dimana penelitian dilakukan, untuk memperoleh data atau informasi berkaitan dengan fokus penelitian. Lokasi penelitian ini ada di DPRD Kabupaten Sidoarjo

\section{Sumber Data}

Dalam penelitian kualitatif tidak mengenal populasi dan sampel pada pendekatan kualitatif yang lebih tepatnya merupakan sumber dats pada situasi sosial. Sumber data yang dipergunakan difokuskan kepada informan, dimana informan dipilih sesuai dengan kasus yang diangkat untuk studi yang sifatnya mendalam (Sukmadinata (2007)

\section{Sampel Penelitian}

Dengan metode pengambilan sample acak. Sesuai degan ruang lingkup penelitian, maka objek penelitian juga dibatasi bahwa informan yang emberikan informasi merupakan orang yang kompeten yang ada dalam lingkungan anggota Dewan Kabupaten Sidoarjo

\section{Prosedur Penelitian}

Penelitian ini merupakan penelitian tindakan yang memerlukan waktu selama 1 tahun. Dalam metode penelitian ini menyampaikan secara terperinci, mencakup garis besar pendekatan penelitian, metode dan prosedur pengumpulan data serta analisis yang akan digunakan untuk mencapai tujuan penelitian.

Tahap pertama peneliti adalah mencari latar belakang permasalahan serta rumusan masalah dari penelitian yang akan dilakukan oleh peneliti, kemudian setelah itu peneliti menentukan objek penelitian serta menentukan informan kunci terkait yang sanggup memberikan informasi untuk menunjang penelitiannya. Tahap selanjutnya, pengumpulan informasi yang dilakukan dengan observasi partisipan, wawancara dan dokumentasi untuk mencari semua informasi yang terkait dengan rumusan masalah serta yang menjadi fokus penelitian, sehingga peneliti mendapatkan jawaban dari rumusan masalah tersebut. Melakukan uji keabsahan data melalui uji kredibilitas data dengan cara triangulasi tes yaitu mengkombinasikan antara observasi, wawancara dan dokumentasi. Analisis data selama di lapangan penelitian menurut Miles and Huberman (1984)

Tahap analisis data dalam tahapan ini peneliti melakukan serangkaian proses analisis data kualitatif sampai pada interpretasi data-data yang diperoleh sebelumnya.Peneliti menganalisis data yang didapatnya kemudian menyusun laporan. Laporan yang didapat selama proses penelitian yang sudah direduksi tersebut, diolah kembali sehingga bisa disusun dengan runtut dan baik menghasilkan sususan pembahasan penelitian yang dianggap sesuai. Sehingga akan mendapatkan kesimpulan dari seluruh informasi dan pendukung yang telah
dikumpulkan.Penelitian ini dilakukan di DPRD Kabupaten Sidoarjo.Obyek penelitian ini adalah para Anggota Dewan Perwakilan Rakyat Daerah Kabupaten Sidoarjo.

Instrumen penelitian Pengetahuan Dewan Tentang Anggaran Dalam Pengawasan Keuangan Daerah (APBD) Di Kabupaten Sidoarjo pada Tabel 1 dan Tabel 2

[Table 1 about here.]

[Table 2 about here.]

\section{Teknik Pengumpulan Data}

Dalam penelitian ini data diperoleh dengan dua cara yaitu

1. Dokumentasi: Teknik dokumentasi pada penelitian ini adalah pengumpulan data yang diperoleh dari catatancatatan, laporan-laporan, serta dokumen-dokumen yang terdapat di DPRD terkait APBD dan pelaporannya.

2. Wawancara: Wawancara dengan beberapa pertanyaan yang mewakili penelitian

\section{HASIL DAN PEMBAHASAN}

Dari hasil penelitian yang dilakukan di DPRD Kabupaten Sidoarjo, dengan melakukan wawancara mendalam kepada Ketua DPRD Kabupaten Sidoarjo dan anggota Komisi C Badan Anggaran. Didapatkan hasil sebagai berikut:

\section{Pengetahuan Dewan Tentang Anggaran}

Dengan pertanyaan yang menyangkut tentang pengetahuan dewan tentang anggaran yaitu :

1. Pengetahuan dewan tentang metode penyusunan RAPBD. Penjelasan dari narasumber pertama tentang metode dan tahapan penyusunan APBD sangat lengkap dan jelas serta hal penyusunan dan perancangan diatur dalam Peraturan Daerah. Dijelaskan bahwa penyusunan APBD ini merupakan implementasi dari rencana pembangunan daerah selama setahun akan tapi dalam baju besarnya itu melaksanakan RPJM selama 5 tahun pemerintahan daerah/salah seorang pimpinan di daerah kabupaten atau kota. Jadi dalam menyusun anggaran APBD tahunan ini pedoman RPJM kemudia dilakukan tahapan-tahapan melalui musyawarah desa, kemudian di tingkat kecamatan dilanjutkan ke kabupaten selanjutnya kemudian Rencana Kerja Unit Pelayanan Daerah kemudian menjadi RKPD . Dalam penyusunan ini, dari tahun 2018 kabupaten Sidoarjo sudah menggunakan e-planning, jadi sudah tidak lagi secara manual maupun offline. Setiap usulan harus masuk melalui sistem.Apabila suatu usulan masuk ke dalam sistem secara tiba-tiba muncul juga tidak diperbolehkan dimana usulan harus ada di RKPD. 
RKPD tidak menjadi wilayah pengawasan dewan juga dikarenakan RKPD merupakan wilayah pengawasan pemerintahan daerah yangkemudian RKPD dibahas oleh pemerintahan dan tim anggaran dengan DPRD dan Badan Anggaran, dan kemudian nanti menjadi kebijakan umum anggaran uang dan menyusun Plafon Priorita Anggaran Sementara. Hal tersebut disusun setelah membahas RKPD bersama tim anggaran dan badan anggaran menuju KUA BPAS. Setelah menyusun KUA BPAS ditetapkan bersama, menyusun Perda APBD dibahas lagi menjadi APBD, bahwa apa yang ada di APBD harus ada di KUA BPAS dan harus ada di RKPD. Setelah disepakati jadi APBD maksimal 30 November 2019 (untuk periode 2019 2020) masih menjadi rancangan Perda. APBD masih di evaluasi oleh gubernur,selama 2 minggu. Akhir desember sudah muncul hasil evaluasinya, kemudian dikembalikan ke DPRD untuk di bahas kembali apa-apa yang menjadi rekomendasi pemerintah provinsi, apa yang boleh dilakukan dan tidak boleh dilakukan muncul di hasil evaluasi tersebut. Setelah hasil evaluasi dari Pemda DPRD maka akan muncul nomor registrasi, maka itu resmi menjadi perda yang di Undangkan untuk satu tahun kedepan..sistemnya buttom up juga top down untuk hasil evaluasinya. Disamping itu usulan lebih besar ketersediaan anggaran di APBD masih 5,2 triliun, tapi kalau diusulan bisa sampai 9 triliun, nanti munculnya di Plafon Prioritas Anggaran Sementara.

Anggaran yang telah dimasukkan dalam di e-planning yang kemudian akan dibahas oleh DPRD akan terdapat koreksi yaitu dihapuskan atau dipangkas dan akan dibuat dalam bentuk katalog

Untuk penjelasan dari narasumber kedua menjabarkan bahwa APBD disusun oleh eksekutif, bagaimana cara menyususn eksekutif itu melalui beberapa tahap, mulai dari musyrik balai desa dibawa ke musyrik kecamatan, kemudian kabupaten dan kemudian dirapatkan disini oleh eksekutif termasuk juga bagaimana menyerap aspirasi dari seluruh elemen masyarakat dan tokoh semuanya. Setelah itu dimulai dari mulai bulan Februari sampai maret, setelah jadi sebuah konsep yang baku bagi eksekutif. Nah dalam bentuk KUABPAS kebijakan umum anggaran dalam bentuk kebijakan secara global itu disodorkan ke kami di DPR. Nah di DPR itu kami bahas kebijakan-kebijakan umumnya, apa saja yang harus dilakukan eksekutif kedepannya/tahun selanjutnya, setelah itu kami kembalikan lagi, kalau sudah selesai dibahas dan digedok/diparipurnakan (diputuskan kebijakan umum) baik plafon pendapatannya maupun plafon belanjanya belum tatanan teknisnya. BUPR atau membentulkan jalan aspal tahun ini berapa, misalny 100 milliyar disepakatkan 100 miliyar, disepakatkan 200 miliyar ya 200 miliyar, belum sampai dibawa kedaerah di mana saja 200 miliyar ini, setelah itu dikembalikan ke eksekutif, kemudian eksekutif memulai kebijakan umum itu dan mendetilkan RAPB melalui dariyang saya ceritakan tadi mulai dari balai desa sampai ke kabupaten. Nah kalau sudah selesai dalam bentuk buku dibawa lagi ke DPR sini kemudian dibahas panjang lebar oleh kami satu persatu dan biasanya dibahas oleh badan anggaran dan badan anggaran melibatkan komisi-komisi, karena detilnya mereka yang tahu, kegiatan ini memakan waktu yang panjang bisa sampai 3 bulan dan maraton, karena disidoarjo APBD sampai 5,5 Triliun, sehingga kita harus rapat secara detil dan jitu dalam menentukan kebijakannya. Setelah itu secara singkat langsung diparipurnakan maksimal bulan november harus selesai untuk dikirim ke gubernur, dan yang mengirimkan eksekutif.

Dari kedua narasumber sangat memahami bagaimana eksekutif melakukan penyusunan RAPBD, mulai dari rapat perencanan, penganggaran dan pengendalian akan tetapi ada perbedaan informasi bahwa dalam perencanaan narasumber pertama menjelaskan sudah memakai siste yaitu e-planning sedangkan narasumber kedua menjelaskan masih memakai kertas atau manual.

\section{Pengetahuan dewan tentang pelaksanaan APBD yang sesuai dengan kebijakan}

Informasi dari narasumber pertama mengenai kesesuaian tentang pelaksanaan dengan kebijakan adalah bahwa untuk melakukan kegiatan pembangunan daerah fisik maupun non fisik selama setahun anggaran itu tetap acuannya adalah APBD, persediaan anggarannya juga APBD kecuali menggunakan dana-dananya untuk CSR bisa menggunakan dana non APBD yang pertanggung jawabannya berbeda dengan pertanggungjawaban APBD. Untuk pengawasannya untuk APBD mungkin belum bisa dilakukan semuanya.Ada yang karena gagal lelang.Dalam rangka pengawasan lebih pada pengawasan kebijakannyaa, tidak pada teknis, Cuma adakalanya dewan harus secara teknis untuk meluruskan sesuatu yang tidak pada aturannya. Kemudian juga ada evaluasi triwulan,dengan mengundang semua Dinas-dinas sesuai dengan satuan kerja masing-masing komisi, dilakukan evaluasi serapan anggarannya telah mencapai berapa persen begitu pula prosentase perencanaannya. Akan dilakukan dalam tiap tiga bulan, itu merupakan ranah pokok DPRD melalui pengawasan APBD. Disamping itu ada sidak dalam setiap sektor pembangunan daerah.

Sedangkan narasumber kedua memberikan jawaban bahwa identifikasi tersebut tidak dapat dilakukan karena melanggar peraturan dan kebijakan yang telah disepakati antara eksekutif dan legislatif.

\section{Pengetahuan dewan ketika terjadi kebocoran dalam pelaksanaan.}

Menurut narasumber pertama kebocoran memang relatif bisa dikatakan jarang berani dilakukan hal-hal seperti itu karena rawan sekali, yang dimaksud kebocoran menurut dewan adalah pelaksanaan yang tidak tepat, contohnya anggaran pengentasan kemiskinan data yang disampaikan eksekutif kepada DPR tidak valid. Ada yang seharusnya menerima tapi tidak menerima, ada yang seharusnya tidak menerima karena sudah mampu tapi tetap tercatat di data terpadu, itu yang kami 
anggap kebocoran, tapi secara regulasi mereka berhak mendapatkan karena nama mereka masih tercantum di basis data terpadu. Jadi kebocoran bagi legislatif adalah kurang akuratnya perencanaan eksekutif sehinggapelaksanaan menjadi tidak tepat sasaran.

Sedangkan menurut narasumber kedua kesalahan penggunaan ada namun bukan wilayah kejaksaan atau penegak hukum. Menurut legislatif biasanya bukan penyelewengan, karena ada rapat triwulan jika terjadi ketidak sesuaian dengan lapangan atau tidak sesuai dengan apa yang disepakati bersama akan dihentikan bersama-sama dan dilibatkan di BPK. Sering terjadi, begitu sebaliknya apabila sudah disepakati tapi tidak dijalankan oleh eksekutif nanti menjadi uang silpa dan hal tersebut merupakan motif politik.

\section{Pengetahuan dewan dalam melakukan identifikasi kegagalan dalam pelaksanaan.}

Penjelasan narasumber pertama tentang identifikasi kegagalan pelaksanaan yang dilakukan legislatif adalah dengan mengundang publik ataupun pihak yang berkepentingan dan berkenaan langsung dengan program pemerintah.Sebagai dasar RAPBD namun tidak semuanya terealisasi.Tapi tentunya tidak hanya melalui riset, tapi juga perjalanan anggota dewan disetiap masing-masing daerah dengan interaksi langsung kepada masyarakat melalui proposal-proposal dari masyarakat yang mana kadang-kadang merasa jenuh melakukan pengajuan kepada pemerintah, itu juga dimungkinkan.

\section{Pengawasan Keuangan Daerah}

Dalam pengawasan keuangan daerah narasumber pertama menyatakan kekhawatirannya dengan pembangunan daerah di Sidoarjo, DPRD Sidoarjo agak malu dengan Surabaya dan Mojokerto (terutama jalannya, Q-red). Walaupun sebenarnya DPRD nya sudah agresif akan tetapi pemerintah daerahnya dalam dinas-dinas terkait kadang enggan membelanjakan anggarannya karena takut diperiksa dan lain sebagainya. Lesgislatif sudah sampaikan ke Pemerintah daerah dan Pemkab Sidoarjo sudah mulai sejak tahun 2018 melakukan pengecoran jalan didaerah Krian, Krembung dan di Porong. Akan tetapi anggaran yang belum disesuaikan. Sehingga DPRD mencoba mendorong eksekutif untuk melakukan penyesuaian sehingga meskipun anggaran terbatas tapi harus tepat dalam menyusun anggaran, sasaran juga tepat dan pelaksanaan juga tepat.

Untuk pengawasannya yang kurang adalah dalam faktor kualitas, dimana dengan anggaran yang seharusnya dapat melaksanakan pembangunan jalan dengan kualitas bagus, akan tetapi diberikan kualitas yang tidak sesuai,dimungkinkan masih ada oknum yang berupaya mengambil keuntungan. Dalam hal ini DPRD sudah sering mem-warning ataupun memberikan peringatan yang cukup keras agar tidak ada penyalahgunaan anggaran ataupun ketidaksesuaian.

Dalam perencanaan anggaran terkadang terdapat perubahan, walaupun perubahan ini bahkan jarang terjadi. Faktor- faktor yang menyebabkan terjadi perubahan antara lain adanya peningkatan PAD, adanya perubahan target baru, perubahan rencana baru yang mengakibatkan perubahan keuangan. Seperti yang pernah terjadi pada tahun 2017 dimana anggaran telah disepakati dalam rapat paripurna dan telah dituangkan dalam Perda ternyata terdapat ketidaksesuaian, dengan kondisi APBD sudah ditetapkan sudah ada nomor registrasinya. Maka DPRD akan menyerahkan pada pemerintah pusat untuk melakukan kaji ulang atas ketidaksesuain.

Sedangkan perubahan anggaran hampir tiap tahun ada, tapi juga pernah tidak ada perubahan, sehingga anggaran itu tidak wajib. Perubahan anggaran itu terjadi disebabkan tiga faktor, yang pertama yaitu peningkatan pendapatan, kemudian ada perubahabntarget maupun kuantitas yang harus diselesaikan kemudian penambahan sebuah perencanaa baru, itu bisa dimungkinkan perubahan anggaran keuangan, akan tetapi revisi anggaran penah terjadi di tahun 2017 ketika APBD sudah ditetapkan ternyata apa yang tertulis di Perda itu tidak sama dengan apa yang disepakati pada paripurna, ada yang terselip entah sengaja atau tidak kemudian menjadi persoalan, APBDnya sudah ditetapkan, sudah ada nomor regestrasinya, sudah sah untuk dilaksanakan tapi pada sisi tahapan penyusunan anggaran itu merupakan pelanggaran, itu kalau tidak dilaksanakan adalah pelanggaran admin, tapi kalau sudah dilaksanakan itu pidana tipikor (memaksukkan anggaran tanpa pembahasan) akhirnya itu dilakukan konsultasi ke Kementerian dalam negeri jadi harus ada surat kesepakatan antara DPR dan Pemerintah daerah bahwa kesepakatan tidak akan menyerap anggaran yang diselipkan itu, itu juga sudah termasuk revisi. Kemudian juga terjadi tanpa ada pembahasan ada di romawi 7, disitu ada 274 miliyar yang kami anggap tanpa pembahasan.Jadi harus saling hati-hati.Kalau anggaran itu di ajukan berarti juga harus dibahas tanpa pembahasan yaa itu di anggap penumpang gelap.

Untuk anggaran yang dimasukkan tanpa pembahasan disepakati untuk tidak digunakan pada periode tersebut, sehingga mengakibatklan nilai silpa yang besar, karena antara legislatif dan eksekutif sama-sama untuk salimng mengingatkan akan penggunaan dana tersebut. Jika legislatif keras makan akan dilaporkan, pemerintah daerah juga harus hati-hati, pada akhirnya 84 miliyar ditambah 247 tidak dibelanjakan dan silpa tahun berikutnya sangat besar, kemudian dipakai untuk periode berikutnya tapi melalui pembahasan.jadi setelah pemerintahan menggunakan APBD selama bulan maret, maksimal satu bulan kedepan itu pemerintah diberikan waktu untuk untuk menyampaikan laporan keterangan pelaksanaan APBD, jadi disambung dengan LKPJ Bupati terhadap APBD tahun sebelumnya. Kemudian akan dibahas selama 1 bulan, akan muncul rekomendasi-rekomendasi untuk perbaikan ditahun berikutnya. Rekomandasi tersebut bisa keras, bisa sedang dan bisa pelan, yang paling penting adalah mengawal rekomandasi itu benar-benar dilaksanakan/diperbaiki atau tidak.Seringkali rekomendasi-rekomendasi tapi tidak ada tindak lanjut.

Kemudian setiap tahun adan temuan BPK, contohnya di pasar Krian ada aset Pemerintah yang dikuasai oleh pihak 
swasta tapi pelaporannya tidak muncul (padahal mungkin ada biaya sewa. Itu setiap UPD pasti ada temuan BPK.Itu mempengaruhi status kita WTP atau tidak.Di dua tahun terakhir ini ada temuan BPK setelah mendapat LHP BPK itu wajib di bahas di DPRD. Kemudian direkomendasikan lagi melalui inspektorat, Bupati melalui rekomendasi DPR bahwa ini harus ditindak lanjuti tapi yaa begitu, UPD itu rata-rata yang jadi kepala dinas seringkali kurang tiga tahun sudah pensiun, biasanya ingin pensiun khusnul khotimah jadi agak takut mengambil kebijakan, karena yang diinginkan orang pensiun kan pensiun yang sejuk, itu yang menjadi kendala saat ini. Ada juga temuan yang sudah dikerjakan oleh desa kemudian masuk masuk perencanaan daerah juga, itu agak berbahaya.

Revisi anggaran itu tidak diperbolehkan selain di KA BAK, di perbolehkan cuma setahun sekali itupun harus sangat darurat atau perintah dari pemerintah pusat. dari dan prosesnya sama seperti menyusun anggaran, kalo cuma satu item ya tidak bisa, sia-sia saja.Sehingga dari bupati itu diserahkan ke kami DPRD dlam rapat paripurna dan setelah itu dibahas melalui pansus/tim khusus, satu bulan dan setelah itu menjadi rekomendasi sehingga terlihat indikasi bahwa bupati kerja apa tidak, mencapai target atau tidak, manfaat atau tidak, disitu terlihat tapi masalahnya itu dalam hasil paripurna dimasukkan kelemari dan tidak dibaca lagi oleh bupati, itu tidak apa. Tidak ada undang-undang-untuk menyatakan apa yang kami

\section{REFERENCES}

Achmadi, A., Mahmuddin, M., Rusmiyati, S., and Wibisono, S. (2002). Good Governance dan Penguatan Instistusi Daerah. Masyarakat Transparansi Indonesia.

Coryanata, I. (2007). Akuntabilitas, Partisipasi Masyarakat, dan Transparansi Kebijakan Publik Sebagai Pemoderating hubungan Pengetahuan Dewan tentang Anggaran dan Pengawasan Keuangan Daerah (APBD). In Simposium Nasional Akuntansi X

Ichsan, M. R. (1997). Administrasi Keuangan Daerah: Pengelolaan dan Penyusunan $A P B D$ (Malang,: Brawijaya Universty Pers).

Miles, M. B. and Huberman, A. (1984). Analisis Data Kualitatif. (Jakarta: Penerbit Universitas Indonesia).

Pramita, Y. D. and Andriyani, L. (2010). Determinasi Hubungan Pengetahuan Dewan Tentang Anggaran dengan Pengawasan Dewan Pada Keuangan Daerah (APBD) Studi Empiris pada DPRD Se-Karesidenan. In Simposium Nasional Akuntansi XIII.

Rubin, I. (1996). Budgeting for Accountability: Municipal Budgeting for the 1990. rekomendasikan harus ditindak lanjuti.

\section{KESIMPULAN}

Dari hasil penggalian informasi dari narasumber maka dapat disimpulkan bahwa anggota dewan sangat memahami bagaimana prosedur dalam perencanaan dan penetapan anggaran yang dilakukan dari tingkat pemerintahan paling bawah yaitu desa hingga mengerucut ke kabupaten. Dengan menggunakan sistem yang disebut sebagai e-planning. Dalam rangkaian perencanaan dan penetapan anggaran tersebut pihak-pihak yang berkepentingan termasuk masyarakat selalu dilibatkan, sehingga akan mengakomodir seluruh kepentingan masyarakat.

Dengan pengetahuan akan anggaran tersebut, maka anggota dewan dapat melakukan pengawasan dan pengendalian terhadap pelaksanaan APBD dalam setiap periode, dimulai setiap triwulan dan akan dilakukan rekomendasi atas hasil kinerja pemerintah atas periode tersebut, yang sayangnya hasil rekomendasi tersebut belum ada tindak lanjut dari pemerintah.

Ucapan Terima Kasih

Peneliti ucapkan terima kasih atas kesediaan anggota dewan Komisi C yang berkenan untuk melakukan wawancara dan memberikan informasi yang cukup akurat.

Journal Public Budgeting \& Finance.

Sukmadinata, N. S. (2007). Metode penelitian pendidikan (Bandung: Remaja Rosdakarya).

Yudoyono, B. (2002). Optimalisasi Peran DPRD dalam Penyelenggaraan Pemerintah Daerah. http://www.bangda.depdagri.go.id/jurnal/jendela/jendela3.

Conflict of Interest Statement: The authors declare that the research was conducted in the absence of any commercial or financial relationships that could be construed as a potential conflict of interest.

Copyright (C) 2019, and. This is an open-access article distributed under the terms of the Creative Commons Attribution License (CC BY). The use, distribution or reproduction in other forums is permitted, provided the original author(s) and the copyright owner(s) are credited and that the original publication in this journal is cited, in accordance with accepted academic practice. No use, distribution or reproduction is permitted which does not comply with these terms. 


\section{LIST OF TABLES}

1 Pengetahuan Dewan Tentang Anggaran . . . . . . . . . . . . . . . . . . . . . . . . . 119

2 Pengawasan Keuangan Daerah

120 
TABLE 1 | Pengetahuan Dewan Tentang Anggaran

\begin{tabular}{ll} 
No & Pernyataan \\
1 & Bagaimana cara penyusunan dan mekanisme dalam penyusunanAPBD? \\
3 & Bagaimana pemahaman saudara dalam pelaksanaan APBD yang seharusnya \\
dilakukan oleh eksekutif ? \\
4 & Bagaimana saudara mampu identifikasi terhadap kesesuaian Anggaran dan \\
& pelaksanaan APBD \\
& Bagaimana saudara mampu mengidentifikasi pemborosan maupun kegagalan \\
\hline
\end{tabular}

Pernyataan

Bagaimana pemahaman saudara dalam pelaksanaan APBD yang seharusnya

Bagaimana saudara mampu mengidentifikasi pemborosan maupun kegagalan 
TABLE 2 | Pengawasan Keuangan Daerah

\begin{tabular}{ll}
\hline No & Pernyataan \\
1 & Seberapa jauh keterlibatan saudara dalammemberikanmasukan saatpenyusunan arah dan kebijakan umum APBD \\
2 & Apakah saudara melakukan analisis politik dalam rangkapenyusunan APBD? \\
3 & Apakah aspirasi masyarakat menjadi dasar saudara dalam rangka menyusun APBD? \\
4 & Bagaimana keterlibatan saudara dalam pengesahan APBD? \\
5 & Apakah saudara dapat menjelaskan tentang APBD yangtelah disyahkan? \\
6 & Apakah menurut saudara pengesahan APBD sudahmemenuhi azaz transparansi? \\
7 & Sejauh mana keterlibatan saudara dalam memantau pelaksanaanAPBD? \\
8 & Bagaimana keaktifan saudara dalam melakukan evaluasi terhadaplaporan triwulanan yang dibuat eksekutif? \\
9 & Jika terdapat revisi yang diajukan oleh eksekutif apakah saudara akan menanyakanalasan adanya revisianggaran? \\
10 & Apakah saudara akan meminta keterangan atas laporan pertanggungjawaban (LPJ) APBD yangdisampaikan Bupati/Walikota? \\
11 & Apa yang saudara lakukan jika dalam LPJ APBD terjadikejanggalan? \\
12 & Apakah ada kejanggalan yang ditemui dalam LPJ APBD dan apa yang dilakukan? \\
\hline
\end{tabular}

